\title{
Library Services Utilization And Satisfaction By Undergraduate Students: A Case Study Of Osun State University Main Library
}

\author{
Onanuga, Ayotola O. Ilori, Olufemi O. Pelemo Grace \\ D. Ogunwande Omolabake O. \\ Serials Librarian, Osun State University Library, Osogbo, Osun State \\ College Librarian, College of Management and Social Sciences Osun State University, Okuku, Osun State \\ College Librarian, College of Education Osun State University, Ipetu-Ijesa, Osun State \\ College Librarian, College of Law Osun State University, Ifetedo, Osun State
}

\begin{abstract}
This study was conducted to assess the library services utilization and satisfaction by undergraduate students in Osun State University main Library, Osogbo, Nigeria. Two hundred and fifty copies of the questionnaire were distributed to students in 200 level and above who formed the sample for the study. Two hundred and twenty two copies were retuned and found usable for the study, given a response rate of $88.8 \%$. The survey research method was adopted for the study. A questionnaire was used as a data collection instrument. Frequency counts and simple percentages were used in analyzing the data collected. The study revealed that majority of the respondents used the library on monthly $81(36.5 \%)$ basis and their main purpose of using the library was to update their knowledge and skills, prepare for test and examination, read library materials, and lecture notes $168(76 \%), 156(70 \%), 153(69 \%), 141(64 \%)$ respectively. The study also discovered that most of the respondents were satisfied with almost all the services provided in the library apart from few services which the library needs to be more effective in delivery. The study recommends that the library should make provision for regular and free internet access, photocopying, printing and inter library loan services in order to improve on their services to the satisfaction the users
\end{abstract}

Key words: Library services, Utilization, Satisfaction and Undergraduate student.

\section{INTRODUCTION}

An effective and efficient academic library is an essential component of any high profile academic institution to serve the students, lecturers as well as other researchers. The main objective of selecting, acquiring, storing, and organizing information in a university library is to aid the academic community in their academic or research pursuit. Libraries are service oriented organizations established for the provision of relevant information resources and quality services to meet and satisfy their users' needs. However, Obama (2005) summarizes the essence of libraries by stating that the library represents the window to a larger world.

\section{BACKGROUND INFORMATION}

Osun State University is the $30^{\text {th }}$ state university and $80^{\text {th }}$ university in Nigeria. It was registered under the laws of the Federal Republic of Nigeria to operate as a state university in December 2006 and is a multicampus institution operating collegiate system. The university's library took off simultaneously with the university to help the institution in carrying out its objectives. There is a library in each of the six campuses namely: Osogbo, Okuku, Ikire, Ejigbo, Ipetu-Ijesa and Ifetedo. The main campus is located at Osogbo and it coordinates the activities of all the other campus libraries and ensures that they all work together to achieve the missions and vision of the university. This study focused on the main campus in Osogbo which has to colleges (college of health sciences and College of Science, Engineering and Technology).

\section{STATEMENT OF THE PROBLEM}

There are different categories of users that make use of university libraries, among these are the undergraduate students. However, it has not been empirically established if the library under study is meeting their needs as the aim of any good library is to meet and satisfy the information needs of all its users and thereby justify its existence. The aim of the study therefore, is to determine the purpose of use of library resources and services and to find out if the undergraduate students are satisfied with the information resources and services of Osun State University main library 


\section{OBJECTIVES OF THE STUDY}

The main objective of this study is to determine the purpose of use of library and whether the undergraduate students are satisfied with the services provided in Osun State University main Library. The specific objectives are to:

1. examine how often the undergraduate students use the library;

2. determine the purpose(s) for which the undergraduate students use the libraries;

3. determine the level of satisfaction with the library services and

4. make recommendations based on the findings for the improvement of service delivery.

\section{LITERATURE REVIEW}

Academic libraries act as regular and up-to-date information providers, which are not separate units but part of the institution and their outcomes must meet the objectives of the parent institution. The library serves as a vital and important channel, where information is acquired, processed and disseminated through the provision of appropriate information resources in various formats including print and non-print. According to Aina (2004) who said, that to the undergraduate students, the library is the learning center because it provides materials that are needed for learning for all the courses that may be offered by the institution. To the teaching staff, the library provides resources to support teaching and research. Above all, he said the library is also expected to provide information sources for extracurricular activities.

A library that is not being utilized is as good as dead as it cannot justify its existence. Therefore, undergraduate students use various library resources and services for various reasons. For instance, Adeniran (2013) examined the usage of electronic resources by undergraduates at the Redeemer's University library, Mowe, Nigeria. The study revealed that the respondents used the electronic resources for research, assignment and current awareness. Also, the use of electronic resources has tremendous impact on the academic performances of the undergraduate students of Redeemer's University; however, there is need for them to acquire more skills to maximize the use of these resources. Also, Onuoha and Subair (2015) assessed library use among undergraduates in Federal Universities in South-West, Nigeria and found out that most of the respondents used the library on daily basis for the purpose of using and borrowing of library materials, internet facility, photocopying and current awareness service. The study concludes by noting that the university library is responsible for meeting the information needs of its community and as such recommends that university libraries endeavour to provide relevant and up-to-date information resouces to attract and retain users. Although the internet may not be the primary purpose for using the library, there is, however, need for libraries to maintain internet facilities considering its worth in information provision.

On the contrary, Onyekweodiri and Agbo (2015) investigated the extent of library utilization by students of veterinary medicine in two federal universities in south-east zone of Nigeria. The result obtained from the findings revealed that library resources required by these students ranges from newspapers, magazines, current awareness services, journals, online resources related to veterinary medicine to many more. On the other hand, library services in both institutions under study are inadequate resulting in student's apathy to the library. Also, a study conducted by Lateef, Omotoso, \& Fagbola (2016) on Students' Use and Evaluation of College Libraries in Crawford University revealed that students use their libraries sparingly; they use the libraries less for references and other academic purposes but more for relaxation in between lectures and to discuss with mates and friends. However, the respondents rate the information resources, services and facilities of the libraries as fair. The study concluded that the resources and services of the college libraries are poorly used and used less for academic purposes. This may not be unconnected with the fair rating of the libraries by the respondents

However, every academic library should be well equipped to make provision for quality services that will justify their existence. This means that all the services provided by the library must be based on how effectively it meets and satisfy the information needs of their users. Therefore, satisfaction can be personal and it is the degree to which users are pleased with the library services, with staff attitudes, and the library environment in fulfilling their needs and expectations. For example, in receiving library services, different users have different expectations. Whereas some users place much emphasis on staff attitude such as being courteous, knowledgeable and willing to help users, others also have high expectations for information resources, while others consider physical facilities as the priority. According to Kitana and Saydam (2014), if a library is able to make available precise information at the time it is needed by users and in a desired form, then, it is providing quality service. Quality library services mean satisfying the requests of the individual user, fully and quickly. For instance, in a situation when a user easily finds the information needed for an assignment, or receives services provided in a friendly environment, it can be described as a positive occurrence and this can lead to a positive impact.

On the other hand, when information needed is not found or the environment is hostile, it may lead to a negative impact. This is affirmed by Daisy (2006) who found that most respondents were very satisfied with 
overall library services and staff performance; moderately satisfied with the print collection; and least satisfied with space and ventilation; lack of study areas and the noisy environment. The helpfulness of the staff was rated the best. Therefore, the availability of facilities enhances the ability of libraries to render necessary services to users. A library may meet the users' information needs by acquiring, organising and making available relevant information resources and services backed by appropriate facilities and delivered through manual or automated means. Bua and Yawe (2014) affirmed the extent to which an academic library services satisfy its users defines how effective or efficient that library is.

\section{METHODOLOGY}

Questionnaire was used as the main instrument for data collection. 250 copies of the questionnaire were randomly distributed by the researchers to students in colleges of Health Sciences and College of Science, Engineering and Technology from 200 level and above. Two hundred and twenty two copies of the questionnaire were returned, representing $89 \%$ response rate. The data obtained were analysed using descriptive statistics of frequency count and percentages and the result is presented in tables and figures.

\section{RESULT AND DISCUSSION}

\section{Demographic InformationFigure 1: Demographic Information (Gender)}

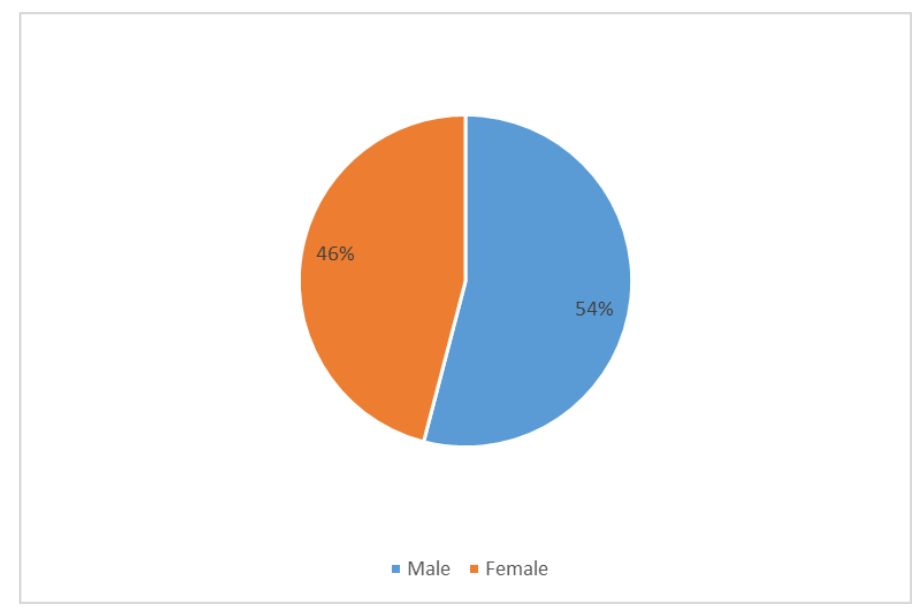

Figure 2: Demographic Information (Faculty)

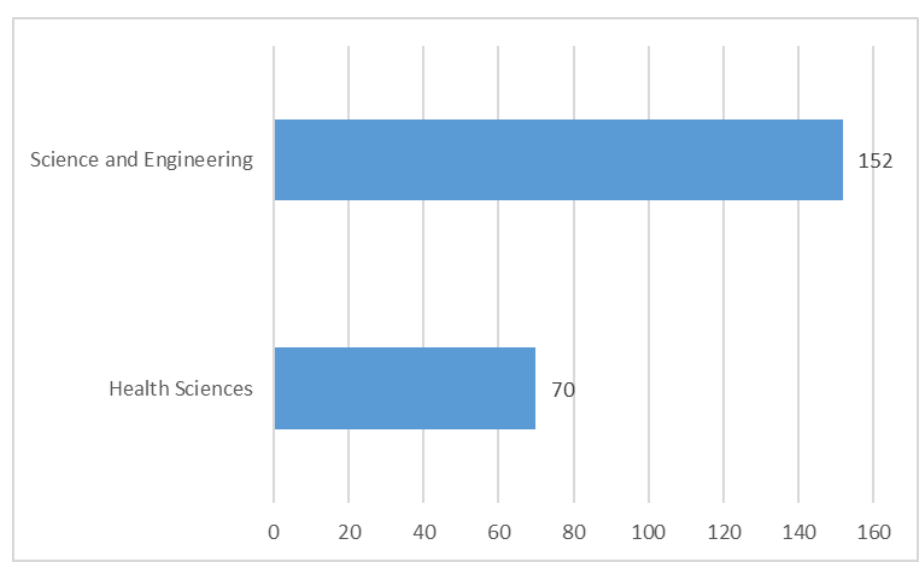

The result of the study indicated that female undergraduate students were in the majority. (54\%) were females and (46\%) were males. The gap between the two genders is not too wide which shows that the male counterparts are also using the library. 152(\%) of the respondents were in faculty of Science, Engineering and Technology (SET) while 70 (\%) respondents came from Health Sciences. This may be attributed to the fact that there were more departments, which translate to more students in faculty of SET than faculty of Health Sciences.

Figure 3: Frequency of Use 


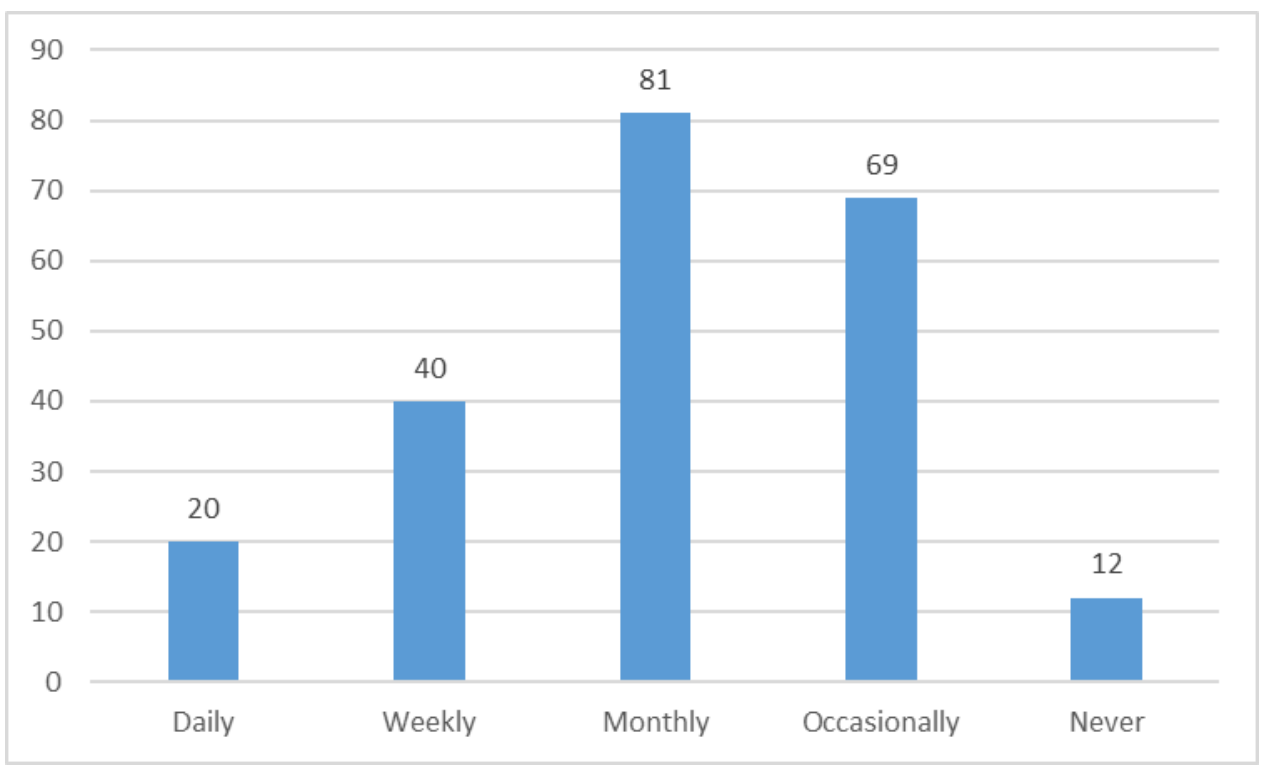

The analysis of the result presented in Figure 3 revealed that majority $81(36.5 \%)$ of the respondents used the library monthly while $69(31.1 \%)$ of the respondents used the library occasionally and $40(18 \%)$ respondents used the library weekly followed by 20(9.2\%) who used the library on a daily basis. The implication here is that majority of the undergraduate students used the library on a monthly, occasionally and weekly basis. This may be due to the fact that majority of the respondents may have other sources of satisfying their information needs. Also, students may be busy during the library with lectures during the opening hours of the library. Hence, the time available for their study might not be sufficient as it is competing with their other activities.

Table 1: Purpose of visiting the library

\begin{tabular}{|r|c|c|c|c|c|}
\hline Purpose of use & SA & A & N & D & SD \\
\hline read my lecture notes & $141(64 \%)$ & $72(32 \%)$ & $6(3 \%)$ & $0(0 \%)$ & $3(1 \%)$ \\
\hline read my personal textbooks & $60(27 \%)$ & $54(24 \%)$ & $6(3 \%)$ & $39(18 \%)$ & $63(28 \%)$ \\
\hline read library materials & $153(69 \%)$ & $57(26 \%)$ & $3(1 \%)$ & $9(4 \%)$ & $0(0 \%)$ \\
\hline consult course materials & $123(55 \%)$ & $54(24 \%)$ & $12(5 \%)$ & $3(1 \%)$ & $30(14 \%)$ \\
\hline consult research materials & $138(62 \%)$ & $51(23 \%)$ & $18(8 \%)$ & $0(0 \%)$ & $15(7 \%)$ \\
\hline borrow library books & $63(28 \%)$ & $48(22 \%)$ & $45(20 \%)$ & $27(12 \%)$ & $39(18 \%)$ \\
\hline update my knowledge and skills & $168(76 \%)$ & $42(19 \%)$ & $0(0 \%)$ & $12(5 \%)$ & $0(0 \%)$ \\
\hline prepare for test and examination & $156(70 \%)$ & $51(23 \%)$ & $0(0 \%)$ & $12(5 \%)$ & $3(1 \%)$ \\
\hline read for personal development & $144(65 \%)$ & $57(26 \%)$ & $6(3 \%)$ & $0(0 \%)$ & $15(7 \%)$ \\
\hline use the Internet & $15(7 \%)$ & $18(8 \%)$ & $60(27 \%)$ & $21(9 \%)$ & $108(49 \%)$ \\
\hline relax and meet friends & $9(4 \%)$ & $21(9 \%)$ & $15(7 \%)$ & $60(27 \%)$ & $117(53 \%)$ \\
\hline leisure/entertainment & $3(1 \%)$ & $12(5 \%)$ & $27(12 \%)$ & $45(20 \%)$ & $135(61 \%)$ \\
\hline Photocopy documents & $33(15 \%)$ & $33(15 \%)$ & $24(11 \%)$ & $78(35 \%)$ & $54(24 \%)$ \\
\hline
\end{tabular}

The respondents were asked to state their reasons for using the library; the analysis of their responses is presented in Table 1. The result revealed that majority of the respondents used the library mainly to update their knowledge and skills, prepare for test and examination, read library materials, and lecture notes $168(76 \%)$, 156(70\%), 153 (69\%), 141 (64\%) respectively. This result disagrees with Onuoha and Subair (2015)'s study that majority of the undergraduate students in Federal Universities in South-West, Nigeria used the library on daily basis for the purpose of using and borrowing of library materials, internet facility, photocopying and current awareness service. Since the library serves as a vital and important channel, where information is acquired, processed and disseminated, adequate provision should always be put in place for the provision of several services that can always attract and retain library users. In addition, this study discovered that very few of the respondents used the library for leisure/entertainment $3(1 \%)$, relaxation and meeting of friends 9 (4\%). This finding also contradict Lateef, Omotoso, \& Fagbola (2016) whose study found out that majority of the undergraduate students of Crawford University used their library more for relaxation in between lectures and to discuss with mates and friends. 
Table 2: Level of Satisfaction with the Library Services

\begin{tabular}{|c|c|c|c|c|c|}
\hline Satisfaction & VS & $\mathrm{S}$ & $\mathrm{N}$ & D & VD \\
\hline \multicolumn{6}{|l|}{ I am satisfied with the: } \\
\hline volumes of reference books in my field of study & $75(34 \%)$ & $60(27 \%)$ & $6(3 \%)$ & $78(35 \%)$ & $3(1 \%)$ \\
\hline number of databases available in my field & $51(23 \%)$ & $72(32 \%)$ & $21(9 \%)$ & $78(35 \%)$ & $0(0 \%)$ \\
\hline currency of the materials in my field & $54(24 \%)$ & $84(38 \%)$ & $12(5 \%)$ & $72(32 \%)$ & $0(0 \%)$ \\
\hline orientation programme provided by the library & $39(18 \%)$ & $84(38 \%)$ & $3(1 \%)$ & $81(36 \%)$ & $15(7 \%)$ \\
\hline number of books I can borrow at a time & $30(14 \%)$ & $81(36 \%)$ & $24(11 \%)$ & $69(31 \%)$ & $18(8 \%)$ \\
\hline opening hours of the library & $84(38 \%)$ & $90(41 \%)$ & $12(5 \%)$ & $36(16 \%)$ & $0(0 \%)$ \\
\hline photocopying services in the library & $9(4 \%)$ & $0(0 \%)$ & $84(38 \%)$ & $96(43 \%)$ & $33(15 \%)$ \\
\hline printing services in the library & $3(1 \%)$ & $63(28 \%)$ & $30(14 \%)$ & $33(15 \%)$ & $93(42 \%)$ \\
\hline $\begin{array}{r}\text { personalized assistance rendered by the library staff } \\
\text { (Reference services) }\end{array}$ & $90(41 \%)$ & $51(23 \%)$ & $24(11 \%)$ & $39(18 \%)$ & $18(8 \%)$ \\
\hline $\begin{array}{r}\text { way the library assist me to get needed materials from } \\
\text { other libraries (Inter library loan) }\end{array}$ & $30(14 \%)$ & $18(8 \%)$ & $87(39 \%)$ & $54(24 \%)$ & $33(15 \%)$ \\
\hline $\begin{array}{r}\text { way the library keeps me abreast of the latest information } \\
\text { in my research area (Selective Dissemination of } \\
\text { Information) }\end{array}$ & $39(18 \%)$ & $81(36 \%)$ & $39(18 \%)$ & $42(19 \%)$ & $21(9 \%)$ \\
\hline \multicolumn{6}{|l|}{ Library Facilities and Equipment } \\
\hline manual (wooden) catalog for searching library materials & $84(38 \%)$ & $90(41 \%)$ & $18(8 \%)$ & $21(9 \%)$ & $9(4 \%)$ \\
\hline $\begin{array}{r}\text { online public access catalog (OPAC) for searching } \\
\text { library materials }\end{array}$ & $18(8 \%)$ & $9(4 \%)$ & $36(16 \%)$ & $69(31 \%)$ & $90(41 \%)$ \\
\hline number of computers available in the e-library & $66(30 \%)$ & $108(49 \%)$ & $12(5 \%)$ & $33(15 \%)$ & $3(1 \%)$ \\
\hline \multicolumn{6}{|l|}{ Attitudes of Library Staff } \\
\hline $\begin{array}{r}\text { ability of the library staff to perform service(s) } \\
\text { dependably and accurately }\end{array}$ & $72(32 \%)$ & $102(46 \%)$ & $27(12 \%)$ & $12(5 \%)$ & $9(4 \%)$ \\
\hline $\begin{array}{r}\text { way the library staff willingly help and respond to my } \\
\text { information needs }\end{array}$ & $66(30 \%)$ & $99(45 \%)$ & $18(8 \%)$ & $33(15 \%)$ & $6(3 \%)$ \\
\hline $\begin{array}{r}\text { level of confidence demonstrated by the library staff in } \\
\text { responding to my information needs }\end{array}$ & $66(30 \%)$ & $99(45 \%)$ & $18(8 \%)$ & $33(15 \%)$ & $6(3 \%)$ \\
\hline $\begin{array}{r}\text { level of understanding from the library staff to my } \\
\text { queries }\end{array}$ & $66(30 \%)$ & $87(39 \%)$ & $36(16 \%)$ & $24(11 \%)$ & $9(4 \%)$ \\
\hline
\end{tabular}

One of the aims of the study is to find out whether the undergraduate students were satisfied with library services. The response to this question is shown in Table 2.

The result from the data analysis indicated that majority of the respondents were satisfied with attitudes of library staff, most of the library facilities and equipment and almost all the services provided in the library apart from photocopying services $9(4 \%)$, printing $3(1 \%)$, free internet access 21 (9\%), inter library loan $30(14 \%)$ and online public access catalog (OPAC) for searching library materials. . It can however, be deduce from the study that the library still needs to improve upon its services especially those areas the respondents were dissatisfied in order to fully satisfy its users. In line with the findings of this study, Daisy (2006) found that most respondents were very satisfied with overall library services and staff performance; moderately satisfied with the print collection; and least satisfied with space and ventilation; lack of study areas and the noisy environment. The helpfulness of the staff was rated the best.

\section{CONCLUSION}

There is no doubt that the role of university library is relevant in achieving the aims of the parent institution, but their continued relevance depends on their services effectively and efficiently satisfies their users. This study has therefore ascertained that undergraduate students do not maximize the use of library services provided for them because majority of the respondents do not use the library on daily and weekly basis. Their main purpose of using the library is to update their knowledge and skills, prepare for test and examination, 
read library materials, and lecture notes. Also most of the respondents were satisfied with almost all the services provided in the library apart from few services which the library needs to be more effective in delivery.

\section{RECOMMENDATIONS}

Based on the findings, the following recommendations are made:

1. Considering the fact that library services were not mostly used on daily and weekly basis, there is need to evaluate their importance in libraries to ascertain if there is need to create more awareness or re-package the services/resources

2. Provision should be made for regular free internet access, which will in turn aid the use of online public access catalog (OPAC) for searching library materials.

In addition to this, adequate training should be given to these students on the use of the library OPAC to ensure optimal use of library resources.

3. Reliable and stable provision should be made for both photocopying and printing services in the library in order to satisfy their users.

4. Library should make adequate provision for inter library loan service in order to help their users get needed information materials from other libraries.

5. Furthermore, the library should establish helpdesk/suggestion box in the library and a very dynamic and competent librarian should man this, to collate the needs of the students and proffer solution to them; by so doing the undergraduate students will see the library as a hub for their academic and research activities.

\section{REFERENCES}

[1] Adeniran, P. (2013). Usage of electronic resources by undergraduates at the Redeemer's niversity, Nigeria. International Journal of Library and Information Science. 5(10), 319-324. Retrieved from DOI: 10.5897/IJLIS2013.0392

Aina, L. O. (2004). Library and information science text for Africa. Ibadan: Third world information services Limited.

[2] Bua, F. T. \& Yawe, A. A. (2014). A comparative study on user satisfaction with the management of library services in three academic libraries in Benue State-Nigeria. Journal of Studies in Social Sciences. 6(1), 23-30.

[3] Daisy, S. (2006). Measuring user satisfaction: a case study at the PGDM branch library at Peradeniya. Journal of the University Librarians' Association, 10:40-53

[4] Kitana, A. \& Saydam, S. (2014). Testing the service quality provided by the University of Girne American Library. International Journal of Business and Social Science. 5(8), 55-61.

[5] Lateef, E. B., Omotoso, A. O. \& Fagbola, B. O. (2016). Students' use and evaluation of College Libraries in Crawford University, Nigeria. Journal of Applied Information Science and Technology, 9(2), 66-76.

[6] Obama, B. (2005). Bound to the World. American Libraries, 36(7), 48-52.

[7] Onuoha, U. D. and Subair, M. O. (2013). Undergraduates' use of libraries in Federal Universities in South-West, Nigeria. Journal of Research \& Method in Education 3(5), 12-17.

[8] Onyekweodiri, N. E. Agbo, A. D. (2015). Utilization of Library Resources by Veterinary Medicine Students in Two Federal Universities in South-East Zone of Nigeria. Global Journal of Human-Social Science, Interdisciplinary 15 (2), 68-75. 